\title{
PENGARUH PENDIDIKAN KEWIRAUSAHAAN,PERAN ORANG TUA TERHADAP INTENSI BERWIRAUSAHA MAHASISWA STKIP PGRI TULUNGAGUNG
}

\author{
Eka Arima Devi ${ }^{1}$, Navik Umurul Hadi ${ }^{2}$ \\ ${ }^{1}$ Mahasiswa Progam Studi Pendidikan Ekonomi STKIP PGRI Tulungagung \\ email : arimaeka@yahoo.com \\ ${ }^{2}$ Dosen Progam Studi Pendidikan Ekonomi STKIP PGRI Tulungagung \\ Email: nafikumurulhadi@gmail.com
}

\begin{abstract}
ABSTRAK
Penelitian ini bertujuan untuk mengetahui pengaruh pendidikan kewirausahaan dan peran orang tua terhadap intensi berwirausaha mahasiswa semesterVI prodi pendidikan ekonomi di stkip pgri tulungagung. berwirausahaan dapat menjadi pilihan alternative mahasiswa setelah lulus, dengan bekal pendidikan kewirausahaan yang diberikan semasa kuliah dan peran orangtua yang mendukung. populasi penelitian mahasiswa semester vi sebanyak 89 mahasiswa, metode pengumpulan data menggunakan angket,analisis data menggunakan regresi linier berganda. Hasil penelitian Uji t terbukti besar nilai $t_{\text {hitung }}(4,832)$,(pendidikan kewirausahaan $X_{1}$ ), (peran orang tua $X_{2}$ ) nilai $t_{\text {hitung }}$ $(4,513)$ dapat disimpulkan secara parsial bahwa "ada pengaruh pendidikan kewirausahaan dan peran orang tua terhadap intensi berwirausaha mahasiswa semester VI prodi pendidikan ekonomi”. Uji $\mathrm{F}$, menunjukkan bahwa nilai $\mathrm{F}_{\text {hitung }}$ $(41,853)>F_{\text {tabel }}(3,10)$. Hal ini menunjukkan ada pengaruh positif variabel pendidikan kewirausahaan dan peran orang tua terhadap intensi berwirausaha mahasiswa semester VI Prodi Pendidikan Ekonomi tahun akademik 2017/2018. $\mathrm{R}^{2}$ adalah 0,493 atau sumbangan efektif dari kedua variabel bebas yaitu 49,3\% terhadap intensi berwirausaha dan sebesar $50,7 \%$ di jelaskan oleh variabel lain yang tidak diteliti.
\end{abstract}

Kata Kunci: Pendidikan Kewirausahaan, Peran Orang Tua, Intensi Berwirausaha

\begin{abstract}
This study aims to determine the effect of entrepreneurship education and the role of parents to the intentions of student entrepreneurship semester VI study of economic education in STKIP PGRI tulungagung. entrepreneurship can be an alternative choice of students after graduation, with the provision of entrepreneurship education provided during the lecture and the role of parents who support. research population of semester VI students as many as 89 students, data collection methods using questionnaires, data analysis using multiple linear regression. The result of the research $t$ test proved great value of tcount $(4,832)$, (entrepreneurship education X1), (parent role X2) tcount value $(4,513)$ can be concluded partially that "there is influence of entrepreneurship education and parent role to intent entrepreneurship student semester VI study economic education ". Test F, indicates that the value of Fcount $(41,853)>$ Ftable (3.10). there is positive influence of variable of entrepreneurship education and parent
\end{abstract}


role to student entrepreneurship intention of semester VI of Prodi Pendidikan Ekonomi academic year 2017/2018. R2 is 0,493 or effective contribution from both independent variable that is $49,3 \%$ to entrepreneurship intention and equal to $50,7 \%$ explained by other variable which not examined. Keywords: Entrepreneurship Education, Role of Parent, Intensi Entrepreneurship

\section{PENDAHULUAN}

Tujuan pembangunan ekonomi berkelanjutan di Indonesia salah satunya yaitu meningkatkan lapangan pekerjaan dan mengurangi pengangguran. Masalah pengangguran masih menjadi salah satu fokus utama yang belum terselesaikan dan tidak bisa dikesampingkan, banyak pihak yang berusaha menurunkan angka pengangguran dengan membuka lapangan pekerjaan hingga sosialisasi berwirausaha. Salah satu penyebab pengangguran yaitu jumlah angkatan kerja yang tidak sebanding dengan tersedianya lapangan perkerjaan.

Menurut data BPS Survei Angkatan Kerja Nasional (Sakernas) tahun 20132017 tentang Pengangguran terbuka menurut Pendidikan Tertinggi yang ditamatkan tahun 2017 telah terjadi penurunan jumlah pengangguran sebesar 16.000 orang menjadi 7,00 juta orang pada agustus 2017 dari Agustus 2016 sebesar 7,03 juta orang. Sementara dari tingkat pendidikan, jumlah pengangguran tertinggi ada pada Sekolah Menengah Akhir (SMA) dibandingkan dengan tingkat pendidikan lainnya sebesar 1.9 juta orang pada tahun 2013-2017. Selanjutnya pengangguran jika dilihat dari jumlah pengangguran tingkat pergutuan tinggi terjadi fluktuasi yaitu pada tahun 2017 jumlah pengangguran tingkat Perguruan Tinggi yaitu 861.695, dengan 242.937 lulusan Diploma dan 618.758 lulusan S1. Hal ini sangat miris sekali, seharusnya para sarjana harus mampu menciptakan pekerjaan dan tidak hanya siap untuk mencari pekerjaan, karena pada kenyataannya mencari pekerjaan sangat sulit meskipun mereka seorang sarjana.

Data Tingkat Pengangguran Terbuka dapat dilihat pada tabel dibawah ini. 


\section{Tabel 1}

\section{Pengangguran Berdasarkan Pendidikan Yang Ditamatkan}

sumber: Data BPS (Sakernas) 2013-2017 (data dalam satuan ribuan)

Salah satu cara mengatasi pengangguran yaitu peningkatan pembangunan

\begin{tabular}{|c|c|c|c|c|c|c|c|c|c|c|c|}
\hline \multirow{2}{*}{$\begin{array}{l}\mathrm{N} \\
\mathrm{O}\end{array}$} & \multirow{2}{*}{$\begin{array}{l}\text { Pendidikan Tertinggi } \\
\text { Yang Ditamatkan }\end{array}$} & \multicolumn{2}{|c|}{2013} & \multicolumn{2}{|c|}{2014} & \multicolumn{2}{|c|}{2015} & \multicolumn{2}{|c|}{2016} & \multicolumn{2}{|c|}{2017} \\
\hline & & Feb & Agt & Feb & Agt & Feb & Agt & Feb & Agt & Feb & Agt \\
\hline 1 & $\begin{array}{l}\text { Tidak/belum pernah } \\
\text { sekolah }\end{array}$ & 112 & 81 & 134 & 74 & 124 & 55 & 94 & 59 & 92 & 62 \\
\hline 2 & Belum/tidak tamat SD & 532 & 489 & 610 & 389 & 603 & 371 & 557 & 384 & 546 & 404 \\
\hline 3 & SD & 1,4 & 1,3 & 1,3 & 1,2 & 1,3 & 1,0 & 1,2 & 1,03 & 1,2 & 904 \\
\hline 4 & SLTP & 1,8 & 1,6 & 1,6 & 1,5 & 1,6 & 1,3 & 1,3 & 1,2 & 1,2 & 1,2 \\
\hline 5 & SLTA Umum & 1,8 & 1,9 & 1,8 & 1,9 & 1,7 & 2,2 & 1,5 & 1,9 & 1,5 & 1,9 \\
\hline 6 & SLTA Kejuruan & 864 & 1,2 & 847 & 1,3 & 1,1 & 1,5 & 1,3 & 1,5 & 1,3 & 1,6 \\
\hline 7 & $\begin{array}{l}\text { Diploma } \\
\text { I,II,III/Akademi }\end{array}$ & 197 & 185 & 195 & 193 & 245 & 251 & 249 & 219 & 249 & 242 \\
\hline 8 & Universitas & 425 & 434 & 398 & 495 & 565 & 653 & 695 & 567 & 606 & 618 \\
\hline & Total & $\begin{array}{c}7,2 \\
4\end{array}$ & 7,41 & 7,14 & 7,24 & 7,45 & 7,56 & 7,02 & 7,03 & 7,00 & 7,00 \\
\hline
\end{tabular}

ekonomi salah satunya yaitu dengan berwirausaha, sangat penting menumbuhkan intensi berwirausaha dari dalam diri . Menurut Yanto (1996:23-24 seperti dikutip Widayoko, 2016) Intensi berwirausaha adalah kemampuan untuk memberanikan diri dalam memenuhi kebutuhan hidup serta memecahkan permasalahan hidup, memajukan usaha atau menciptakan usaha baru dengan kekuatan yang ada pada diri sendiri.

Keputusan untuk memilih berwirausaha berpeluang menciptakan lapangan kerja dan menghasilkan pendapatan lebih besar serta tidak terikat oleh aturan-aturan perusahaan. Menurut Alma 2011 "Seorang wirausaha adalah orang yang melihat adanya peluang kemudian menciptakan sebuah organisasi untuk memanfaatkan peluang tersebut." Kewirausahaan dapat diajarkan melalui pendidikan serta pelatihan. Menurut Alma 2011 "tingkat pendidikan juga penting bagi wirausaha, terutama dalam menjaga kontinuitas usahanya dan mengatasi segala masalah yang dihadapi diperlukan tingkat pendidikan yang memadai”. Pendidikan kewirausahaan adalah usaha yang dilakukan secara sadar untuk mengubah semangat, sikap, 
perilaku dan kemampuan seseorang dalam menangani kegiatan yang mengarah pada upaya mencari, menciptakan dan menerapkan cara kerja, teknologi dan produk baru secara efisiensi guna memberikan pelayanan yang lebih baik atau memperoleh keuntungan yang lebih besar. (Yuniasanti \& Esterlita, 2014).

Penelitian yang dilakukan oleh (Yuniasanti \& Esterlita, 2014) yang berjudul "Pengaruh Pendidikan Kewirausahaan terhadap Intensi Berwirausaha Mahasiswa Universitas Mercu Buana Yogyakarta" menunjukkan ada hubungan antara pendidikan kewirausahaan dan intensi berwirausaha . Pendidikan Kewirausahaan dalam perguruan tinggi sangat penting, hal ini karena wirausaha mampu mendorong laju pertumbuhan, seperti yang diungkapkan Zimmerer, (2002 seperti dikutip Santi et al., 2017) Pada saat sebuah universitas mengajarkan pengetahuan dan memberikan inspirasi yang memadai mengenai kewirausahaan maka memungkinkan untuk meningkatkan keinginan berwirausaha pada kalangan generasi muda.

Upaya pendidikan kewirausahaan mulai dilakukan oleh kalangan institusi pendidikan, termasuk Perguruan Tinggi. Kurikulum yang telah memasukkan pendidikan kewirausahaan atau mata kuliah kewirausahaan telah marak, namun demikian hasilnya masih belum seberapa terlihat. Berdasarkan kondisi tersebut, maka perguruan tinggi negeri maupun swasta juga memiliki tanggung jawab untuk ikut menyiapkan mahasiswanya menjadi wirausaha yang unggul agar tidak menggantungkan lowongan pekerjaan pada pihak lain, salah satunya yang dilakukan oleh STKIP PGRI Tulungagung yang sudah memasukkan pendidikan kewirausahaan didalam mata kuliah.

Berdasarkan hasil observasi dan pengamatan yang telah dilakukan dengan mahasiswa di STKIP PGRI Tulungagung pada mahasiswa prodi pendidikan ekonomi semester VI, peneliti juga mewawancarai beberapa mahasiswa, hasil terlihat bahwa intensi berwirausaha mahasiswa masih tergolong rendah, hal tersebut dapat dibuktikan dengan sikap dari mahasiswa ketika mahasiswa menempuh mata kuliah pendidikan kewirausahaan dan praktik kewirausahaan, mereka tidak memiliki keyakinan dalam diri bahwa mata kuliah ini penting untuk 
berwirausaha dimasa depan, mereka kurang menyerap ilmu yang diberikan dengan maksimal. Seharusnya mereka mampu berfikir bahwa berwirausaha merupakan bagian dari rencana masa depan setela lulus kuliah, dan tidak hanya mengandalkan gelar sarjana sebagai bahan mencari kerja, mereka harus tau betapa sulitnya mencari kerja, maka mereka akan mulai berwirausaha dengan melihat peluang yang ada dan dari dasar ilmu yang telah diberikan semasa kuliah.

Bambang B.U, Dkk (2012, seperti dikutip Fradani, 2014) menyatakan bahwa intensi berwirausaha siswa dipengaruhi oleh peran orang tua dalam mendidik atau membimbing dan mengarahkan anaknya untuk memiliki sikap berwirausaha. Dalam hal ini peran orangtua dalam berpartisipasi untuk mendukung anaknya sebagai mahasiswa yang memiliki niat ingin berwirausaha misalkan ketika orangtua melihat anaknya antusias dan sepenuh hati dalam mengerjakan tugas praktik kewirausahaan, lalu orangtua memberikan dukungan berupa modal kepada anaknya dan nasehat terkait pilihan wirausaha. Peran orang tua dalam pembentukan dan pengembangan intensi berwirausaha pada anak sangat dibutuhkan, namun tidak banyak orang tua yang menyadari hal itu, mereka hanya mengandalkan sistem pendidikan formal, seharusnya semua pihak bekerja sama dan bertanggung jawab atas pendidikan anak. Depdikbud mendifisikan peran diartikan sebagai perangkat tingkah yang dimiliki oleh orang yang berkedudukan dimasyarakat. Sedangkan peranan diartikan sebagai tindakan yang dilakukan oleh seseorang di suatu peristiwa.

Menurut Tony, (2007:120 seperti dikutip Sari, 2013), lingkungan keluarga terutama orang tua akan memberi corak budaya, suasana rumah, pandangan hidup dan juga pola yang akan menentukan sikap dan perilaku terhadap anak-anaknya. Kemandirian dan fleksibilitas orang tua akan melekat dan menurun kepada anaknya apabila kedua orang tua bergelut sebagai seorang wirausaha. Tentunya orang tua yang bekerja sebagai wirsausaha akan mengarahkan, mendukung dan mendorong kemandirian, berprestasi dan bertanggungjawab pada diri anaknya, sampai kemandirian itu tumbuh pada diri anak dan memiliki ketekatan untuk memulai usaha sendiri. Menurut Soelaeman, (2002 seperti dikutip Sari, 2013) salah satu 
Devi, Hadi. Pengaruh Pendidikan Kewirausahaan, Peran Orang Tua Terhadap Intensi...

fungsi dan peran orang tua dalam bidang ekomomi adalah Orang tua bertanggungjawab dalam membiayai kehidupan anak-anaknya, mendidik mereka untuk mengambil sikap yang tepat terkait dengan uang, memberi pendewasaan mengenai ekonomi, bila anak sudah cukup matang diberitahu. Penelitian yang dilakukan oleh(Etriyani \& Purwanto, 2014) yang berjudul "Pengaruh kreatifitas, peran orang tua dan efikasi diri terhadap intensi berwirausaha siswa kompetensi keahlian administrasi perkantoran SMK 1 Pengasih.” yang menunjukkan bahwa terdapat pengaruh positif dan signifikan peran orang tua terhadap intensi berwirausaha.

Berdasarkan fenomena yang terjadi diatas, peneliti ingin mengadakan penelitian untuk mengetahui pengaruh variabel pendidikan kewirausahaan dan peran orang tua terhadap intensi berwirausaha mahasiswa Prodi Pendidikan Ekonomi semester VI di STKIP PGRI Tulungagung. Tahun Akademik 2017/2018”. Dengan tujuan penelitian sebagai berikut:

1. Mengetahui Pengaruh Pendidikan Kewirausahaan terhadap Intensi Berwirausaha Mahasiswa Semester VI Prodi Pendidikan Ekonomi di STKIP PGRI Tulungagung tahun akademik 2017/2018.

2. Mengetahui Pengaruh Peran Orang Tua terhadap Intensi Berwirausaha Mahasiswa Semester VI Prodi Pendidikan Ekonomi di STKIP PGRI Tulungagung tahun akademik 2017/2018.

3. Mengetahui Pengaruh Pendidikan Kewirausahaan dan Peran Orang Tua terhadap Intensi Berwirausaha Mahasiswa Semester VI Prodi Pendidikan Ekonomi di STKIP PGRI Tulungagung tahun akademik 2017/2018.

\section{METODE}

Menurut Sugiyono (2015:3) secara umum metode penelitian diartikan sebagai cara ilmiah untuk mendapatkan data dengan tujuan dan kegunaan tertentu. Cara ilmiah berarti kegiatan penelitian itu dilakukan didasarkan pada cirri-ciri keilmuan, yaitu rasional, empiris dan sistematis. Rasional berarti kegiatan 
penelitian itu dilakukan dengan cara-cara yang masuk akal, sehingga terjangkau oleh penalaran manusia. Empiris berarti cara-cara yang dilakukan itu dapat diamati oleh indera manusia, sehinngga orang lain dapat mengamati dan mengetahui caracara yang digunakan.. Sistematis artinya, proses yang digunakan dalam penelitian itu menggunakan langkah-langkah tertentu yang bersifat logis.

Penelitian dilakukan di STKIP PGRI Tulungagung. Penelitian ini menggunakan rancangan penelitian kuantitatif yang merupakan rancangan penelitian non eksperimen yang bersifat korelasi,

Subjek penelitiannya adalah mahasiswa semester VI Prodi Pendidikan Ekonomi tahun akademik 2017/2018. Sampel penelitian keseluruhan jumlah mahasiswa yang berjumlah 89. teriri dari 45 mahasiswa kelas VI A dan 44 mahasiswa kelas VI B.

Adapun metode pengumpulan data menggunkan angket dan dokumentasi, yang bertujuan untuk memperoleh data mengenaio pendidikan kewirausahaan dan peran orang tua terhadap intensi berwirausaha, pernyataan dalam angket disajikan dalam bentuk skala likert.

Analisis menggunakan uji regresi linier berganda, pengujian hipotesis menggunakan uji koefisien determinasi $\left(\mathrm{R}^{2}\right)$, uji parsial (ujii t), dan uji simultan (uji F), sedangkan pengelolaan data menggunakan Progam SPSS 16.

\section{HASIL DAN PEMBAHASAN}

\section{HASIL}

\section{A. Regresi Linier Berganda}

Analisis regresi linier berganda di gunakan untuk membuktikan sejauh mana pengaruh pendidikan kewirausahaan dan peran orang tua terhadap intensi berwirausaha. Dari hasil uji regresi linier berganda, dapat dilihat pada tabel 1 dibawah: 
Tabel 2

\section{Hasil Analisis Regresi Linier Berganda}

\begin{tabular}{|c|c|c|c|c|c|}
\hline \multicolumn{6}{|c|}{ Coefficients $^{a}$} \\
\hline \multirow[b]{2}{*}{ Model } & \multicolumn{2}{|c|}{ Unstandardized Coefficients } & \multirow{2}{*}{\begin{tabular}{|c}
$\begin{array}{c}\text { Standardized } \\
\text { Coefficients }\end{array}$ \\
Beta
\end{tabular}} & \multirow[b]{2}{*}{$\mathrm{t}$} & \multirow[b]{2}{*}{ Sig. } \\
\hline & $\mathrm{B}$ & Std. Error & & & \\
\hline $1 \quad$ (Constant) & 17.581 & 6.270 & & 2.804 & .006 \\
\hline Pendidikan Kewirausahaan & .413 & .085 & .422 & 4.832 & .000 \\
\hline Peran Orang Tua & .360 & .080 & .394 & 4.513 & .000 \\
\hline
\end{tabular}

a. Dependent Variable: Intensi Berwirausaha

Dari hasil uji regresi linier berganda, maka diperoleh persamaan regresi sebagai berikut:

$$
\begin{aligned}
& Y=\alpha+b_{1} X_{1}+b_{2} X_{2} \\
& Y=17,581+0,413 X_{1}+0,360 X_{2}
\end{aligned}
$$

dengan penjelasan sebagai berikut :

1) a merupakan konstanta yang besarnya 17,581 menyatakan bahwa jika variabel independen (biaya pendidikan kewirausahaan dan peran orang tua) sebesar 0 (nol), maka nilai variabel dependen (intensi berwirausaha mahasiswa semester VI Prodi Ekonomi STKIP PGRI Tulungagung) sebesar 17,581

2) b1 merupakan koefisien regresi dari X1 (pendidikan kewirausahaan ). Koefisien regresi 0,413 menyatakan bahwa setiap penambahan satu satuan variabel X1 (biaya pendidikan) dengan asumsi variabel lain (X2) dianggap konstan maka hal ini akan berpengaruh pada peningkatan besarnya $\mathrm{Y}$ (intensi berwirausaha mahasiswa semester VI Prodi Ekonomi STKIP PGRI Tulungagung) sebesar 0,413 
Devi, Hadi. Pengaruh Pendidikan Kewirausahaan, Peran Orang Tua Terhadap Intensi...

3) b2 merupakan koefisien regresi dari $\mathrm{X} 2$ (peran orang tua). Koefisien regresi 0,360 menyatakan bahwa setiap penambahan satu satuan variabel X2 (peran orang tua) dengan asumsi variabel lain (X1) dianggap konstan maka hal ini akan berpengaruh pada peningkatan besarnya $\mathrm{Y}$ (intensi berwirausaha mahasiswa semester VI Prodi Ekonomi STKIP PGRI Tulungagung) sebesar 0,360

\section{B. Uji Hipotesis}

Pengujian hipotesis bertujuan untuk membuktikan hipotesis yang diajukan dalam penelitian, apakah diiterima atau ditolak. Uji hipotesis dalam penelitian ini terdiri dari uji $\mathrm{t}$ dan uji $\mathrm{F}$ yang dilakukan untuk mengetahui pengaruh variabel bebas pendidikan kewirausahaan $\left(\mathrm{X}_{1}\right)$ dan peran orang tua $\left(\mathrm{X}_{2}\right)$ terhadap variabel terikat intensi berwirausaha $(\mathrm{Y})$ baik secara parsial maupun simultan.

\section{Hasil Uji t}

Tabel 3

Hasil Uji t

Coefficients $^{\mathrm{a}}$

\begin{tabular}{|c|c|c|c|c|c|c|}
\hline \multirow[b]{2}{*}{ Mode } & & \multicolumn{2}{|c|}{ Unstandardized Coefficients } & \multirow{2}{*}{\begin{tabular}{|c|}
$\begin{array}{c}\text { Standardized } \\
\text { Coefficients }\end{array}$ \\
Beta \\
\end{tabular}} & \multirow[b]{2}{*}{$\mathrm{t}$} & \multirow[b]{2}{*}{ Sig. } \\
\hline & & B & Std. Error & & & \\
\hline \multirow[t]{3}{*}{1} & (Constant) & 17.581 & 6.270 & & 2.804 & .006 \\
\hline & Pendidikan Kewirausahaan & .413 & .085 & .422 & 4.832 & .000 \\
\hline & Peran Orang Tua & .360 & .080 & .394 & 4.513 & .000 \\
\hline
\end{tabular}

a. Dependent Variable: Intensi Berwirausaha 
Berdasarkan hasil analisis sesuai tabel 3 diatas, maka pengaruh masingmasing Variabel bebas yang mempengaruhi intensi berwirausaha adalah:

a. Hipotesis 1, Variabel Pendidikan kewirausahaan $\left(\mathrm{X}_{1}\right)$ memiliki sig. $\mathrm{t}<$ alpha yaitu sebesar $0,000<0,05$ dan $t_{\text {hitung }}>t_{\text {tabel }}$ yaitu sebesar 4,832>1,98729. Apabila signifikansi $t<$ alpha atau $t_{\text {hitung }}>t_{\text {tabel, }}$ maka nilai hipotesis nol $\left(\mathrm{H}_{0}\right)$ ditolak dan hipotesis alternative $\left(\mathrm{H}_{\mathrm{a}}\right)$ diterima. Dengan demikian dapat disimpulkan bahwa terdapat pengaruh signifikan antara pendidikan kewirausahaan $\left(\mathrm{X}_{1}\right)$ terhadap Intensi berwirausaha.

b. Hipotesis 2, Variabel Peran orang tua $\left(\mathrm{X}_{2}\right)$ memiliki sig. $\mathrm{t}<$ alpha yaitu sebesar $0,000<0,05$ dan $t_{\text {hitung }}>t_{\text {tabel }}$ yaitu sebesar 4,513 > 1,98729. Apabila signifikansi $\mathrm{t}<$ alpha atau $t_{\text {hitung }}>t_{\text {tabel, }}$ maka nilai hipotesis nol $\left(\mathrm{H}_{0}\right)$ ditolak dan hipotesis alternative $\left(\mathrm{H}_{\mathrm{a}}\right)$ diterima. Dengan demikian dapat disimpulkann bahwa terdapat pengaruh signifikan antara peran orang tua $\left(\mathrm{X}_{2}\right)$ terhadap Intensi berwirausaha mahasiswa.

\section{Hasil Uji F}

\section{Tabel 4}

\section{Hasil Uji F}

\section{ANOVA $^{b}$}

\begin{tabular}{|c|c|c|c|c|c|c|}
\hline \multicolumn{2}{|c|}{ Model } & Sum of Squares & df & Mean Square & $\mathrm{F}$ & Sig. \\
\hline 1 & Regression & 2499.336 & 2 & 1249.668 & 41.853 & $.000^{2}$ \\
\hline & Residual & 2567.855 & 86 & 29.859 & & \\
\hline & Total & 5067.191 & 88 & & & \\
\hline
\end{tabular}

a. Predictors: (Constant), Peran Orang Tua, Pendidikan Kewirausahaan

b. Dependent Variable: Intensi Berwirausaha 
Dari hasil analisis data menggunakan Progam SPSS 16 diperoleh nilai $F_{\text {hitung }}(41,853)>F_{\text {tabel }}(3,10)$ dengan tingkat signifikansi $0,000<$ 0,05. Hal ini membuktikan bahwa ada pengaruh pendidikan kewirausahaan $\left(X_{1}\right)$ dan peran orang tua $\left(X_{2}\right)$ terhadap intensi berwirausaha (Y) mahasiswa prodi pendidikan ekonomi STKIP PGRI Tulungagung seacara simultan atau bersama-sama.

\section{Uji Koefisien Determinasi}

\section{Tabel 5}

\section{Uji Koefisien Determinasi}

Model Summary

\begin{tabular}{|r|r|r|r|r|}
\hline & & & & \\
Model & $\mathrm{R}$ & $\mathrm{R}$ Square & Adjusted R Square & \multicolumn{2}{c|}{$\begin{array}{c}\text { Std. Error of the } \\
\text { Estimate }\end{array}$} \\
\hline 1 & $.702^{\mathrm{a}}$ & .493 & .481 & \\
\hline
\end{tabular}

a. Predictors: (Constant), Peran Orang Tua, Pendidikan Kewirausahaan

Berdasarkan analisis data dengan menggunakan Statistical Product and Service Solution (SPSS) version 16 diperoleh Angka R yang didapat 0,702 artinya korelasi antara variabel pendidikan kewirausahaan dan Peran Orang Tua terhadap intensi berwirausaha mahasiswa prodi pendidikan ekonomi semester VI sebesar 0,702. Hal ini berarti terjadi hubungan yang tidak terlalu erat karena nilai yang tidak mendekati 1. Nilai koefisien determinan $\left(r^{2}\right)$ dari persamaan regresi adalah sebesar 0,493 Hal ini menunjukkan bahwa 49,3\% perubahan variabel $\mathrm{Y}$ (intensi berwirausaha mahasiswa prodi pendidikan ekonomi semester VI STKIP PGRI Tulungagung) dipengaruhi oleh perubahan $\mathrm{X}_{1}$ (pendidikan kewirausahaan) dan $\mathrm{X}_{2}$ (peran orang tua) sedangkan sisanya 50,7\% dipengaruhi oleh faktorfaktor diluar variabel dalam penelitian ini. 


\section{Sumbangan Efektif dari Variabel Bebas dan Variabel Terikat.}

Sumbangan efektif digunakan untuk mengetahui nilai sumbangan yang diberikn semua variabel yang dapat mempengaruhi intensi berwirausaha mahasiswa.

Tabel 6

Hasil Koesifien Korelasi

\begin{tabular}{ccccc}
\hline No & Variabel & $\begin{array}{c}\text { Koefisien Regresi } \\
(\beta)\end{array}$ & $\begin{array}{c}\text { Koefisien } \\
\text { Korelasi }\end{array}$ & R Sequare \\
\cline { 1 - 4 } 1 & $\mathrm{X}_{1}$ & 0,422 & 0,611 & 0,493 \\
\hline 2 & $\mathrm{X}_{2}$ & 0,394 & 0,596 & \\
\end{tabular}

Sumber : Data Hasil Olahan Peneliti,2018

Hasil perhitungan sumbangan efektif dapat dilihat pada tabel berikut,

Tabel 7

Hasil Perhitungan Sumbangan Efektif

\begin{tabular}{ccc}
\hline No & Variabel & Sumbangan Efektif \\
\hline 1 & $\mathrm{X}_{1}$ & $25,7842 \%$ \\
\hline 2 & $\mathrm{X}_{2}$ & $23,4824 \%$ \\
\hline & Total & $49,2666 \%$ dibulatkan $49,3 \%$
\end{tabular}

Sumber : Data Hasil Olahan Peneliti,2018

Berdasarkan table 6 Variabel Pendidikan Kewirausahaan memberikan sumbangan efektif sebesar 25,7842\%, variabel Peran Orang Tua memberikan sumbangan efektif sebesar 23,4824. Hal ini menunjukkan bahwa Pendidikan Kewirausahaan dan Peran Orang Tua mampu mempengaruhi Intensi Berwirausaha sebesar 49,3\%. Sisanya sebesar 50,7\% adalah sumbangan lain yang disebabkan oleh variabel di luar penelitian. 


\section{PEMBAHASAN}

1. Pengaruh pendidikan kewirausahaan terhadap intensi berwirausaha .

1. Berdasarkan hasil analisis data dan uji hipotesis yang dilakukan oleh peneliti dari angket yang disebar kepada mahasiswa, diketahui pendidikan kewirausahan berpengaruh signifikan terhadap intensi berwirausaha. Hal ini dapat dibuktikan dengan hasil analisis nilai sig. $\mathrm{t}$ $<$ alpha yaitu sebesar $0,000<0,05$ dan $t_{\text {hitung }}>t_{\text {tabel }}$ yaitu sebesar 4,832> 1,98729., maka nilai hipotesis nol $\left(\mathrm{H}_{0}\right)$ ditolak dan hipotesis alternative $\left(\mathrm{H}_{\mathrm{a}}\right)$ diterima. Dengan demikian dapat disimpulkan bahwa terdapat pengaruh signifikan antara pendidikan kewirausahaan $\left(\mathrm{X}_{1}\right)$ terhadap Intensi berwirausaha mahasiswa prodi pendidikan ekonomi semester VI STKIP PGRI Tulungagung, artinya pendidikan kewirausahaan memiliki pengaruh positif dan signifikan terhadap suatu intensi berwirausaha mahasiswa, dengan pengembangan ide-ide dan ketrampilan berwirausaha sehingga dengan adanya pendidikan kewirausahaan akan memunculkan keyakinan dalam diri mahasiswa untuk memulai sebuah usaha. Variabel pendidikan kewirausahaan memberikan sumbangan efektif sebesar $25,7842 \%$.

Hasil penelitian ini didukung oleh penelitian yang dilakukan Nur Santi , Amir Hamzah , Teti Rahmawati 2017 hasil penelitian menunjukkan $\mathrm{t}_{\text {hitung }}>\mathrm{t}$ tabel yaitu sebesar 5,666>1,967yang menyatakan menunjukan bahwa variabel pendidikan kewirausahaan mempunyai pengaruh positif dan signifikan terhadap intensi berwirausaha pada mahasiswa Universitas Kuningan.

Penelitian sebelumnya oleh Arie Eko Cahyono (2014), dalam penelitiannya yang Berjudul Pengaruh Pendidikan Kewirausahaan Melalui Variabel Intervening Teori Perilaku Terencana Terhadap Intensi Berwirausaha Mahasiswa Fakultas Keguruan Dan Ilmu Pendidikan Universitas Jember. Koefisien jalur dari variabel pendidikan kewirausahaan terhadap intensi berwirausaha mahasiswa FKIP Universitas Jember diperoleh skor pengaruh langsung sebesar 0,30 dengan arah positif, yang berarti bahwa semakin baik pendidikan kewirausahaan semakin baik intensi berwirausaha mahasiswa FKIP Universitas Jember. Hasil analisis t-tes diperoleh skor $\mathrm{t}$ sebesar 1,52 
yang berarti lebih kecil dari taraf signifikansi 5\%, yakni 1,96, atau $\mathrm{t}=$ $1,52>$ t.s. $5 \%=1.96$, sehingga secara statistik pengaruh pendidikan kewirausahaan terhadap intensi berwirausaha mahasiswa FKIP Universitas Jember adalah tidak signifikan.

Penelitian lain yang dilakukan oleh (Trisnawati, 2011) menunjukkan bahwa pendidikan kewirausahaan tidak memiliki pengaruh terhadap intensi berwirausaha, dalam penelitiannya hanya variabel sikap yang mempengaruhi intensi berwirausaha seorang mahasiswa. Hal senada juga diungkapkan (Mutohar, 2017) Berdasarkan hasil analisis hipotesis keempat, maka dapat disimpulkan bahwa koefisien regresi Pendidikan Kewirausahaan (X4) mempunyai pengaruh yang negatif terhadap variabel intensi berwirausaha. Sedangkan nilai koefisiensebesar(0,022)artinya bahwa penurunan variabel pendidikan kewirausahaan dengan memperhatikan pemahaman dan pengetahuan kewiraushaanpada mahasiswa maka akan meningkatkan intensi berwirausaha mahasiswa sebesar -0,022. Hasil uji signifikan menggunakan ujit menunjukkan bahwa, variabel Pendidikan Kewirausahaan (PK X3) diperoleh nilai t hitung sebesar -0,708. Oleh karena nilai thitung lebih kecil dari ttabel 1,662 dan probabilitas signifikansi untuk pendidikan kewirausahaan sebesar 0,480>0,05; maka H0 diterima, yang berarti bahwa pendidikan kewirausahaan tidak berpengaruh terhadap intensi berwirausaha mahasiswa.

\section{Pengaruh peran orang tua terhadap intensi berwirausaha.}

Berdasarkan hasil analisis data dan uji hipotesis yang dilakukan oleh peneliti dari angket yang disebar kepada mahasiswa, diketahui pendidikan kewirausahan berpengaruh signifikan terhadap intensi berwirausaha. Hal ini dapat dibuktikan dengan hasil analisis variabel Peran orang tua $\left(\mathrm{X}_{2}\right)$ memiliki sig. $\mathrm{t}<$ alpha yaitu sebesar $0,000<0,05$ dan $t_{\text {hitung }}>t_{\text {tabel }}$ yaitu sebesar 4,513 $>1,98729$, maka nilai hipotesis nol $\left(\mathrm{H}_{0}\right)$ ditolak dan hipotesis alternative $\left(\mathrm{H}_{\mathrm{a}}\right)$ diterima. Dengan demikian dapat disimpulkann bahwa terdapat pengaruh signifikan antara peran orang tua $\left(\mathrm{X}_{2}\right)$ terhadap Intensi berwirausaha mahasiswa prodi pendidikan ekonomi semester VI STKIP PGRI Tulungagung. Artinya bahwa variabel peran orang tua mempengaruhi secara positif dan signifikan terhadap intensi berwirausaha, hal ini menun jukkan bahwa peran orang tua penting dalam memotivasi,mendukung anak agar tumbuh intensi berwirausaha pada anak. Variabel peran orang tua memberikan sumbangan efektif sebesar $23,4824 \%$ 
Hasil penelitian ini didukung oleh Yustina Evi Etriyani dan Purwanto 2014 menyatakan bahwa Peran orangtua berpengaruh terhadap intensi berwirausaha siswa Kompetensi Keahlian Administrasi Perkantoran SMK Negeri 1 Pengasih. Hal tersebut dibuktikan dengan nilai $r$ hitung sebesar 0,738 bernilai positif sehingga hipotesis tersebut positif. Selain itu, hail penelitian juga diperkuat oleh penelitian yang dilakukan penelitian Arum Kartika Sari (2013) dengan judul penelitian nya Pengaruh Peran Orang Tua, Guru, Dan Self-Efficay Terhadap Kesiapan Berwirausaha Siswa Smk Muhammadiyah 1 Bantul Kompetensi Keahlian Audio Video Kelas XII. Uji hipotesis pertama menemukan bahwa peran orang tua berpengaruh positif dan signifikan terhadap kesiapan berwirausaha sebesar 0,289 (sig. 0,023). Hasil penelitian ini menunjukkan bahwa dengan nilai $r$ hitung sebesar 0,289 yang berarti tidak terdapat tanda negatif pada $r$ hitung tersebut, sehingga hipotesis tersebut positif. Sedangkan harga $r$ hitung 0,289 yang lebih besar dari pada $r$ tabel 0,244 dengan $\mathrm{N}=62$ dan taraf signifikansi 5\%, sehingga dapat disimpulkan bahwa hipotesis tersebut bernilai signifikan.

Hasil Penelitian ini juga didukung oleh hasil penelitian yang dilakukan (Sari, 2013) Hasil penelitian ini menunjukkan bahwa terdapat pengaruh positif dan signifikan dari Peran Orang Tua (X1) terhadap Kesiapan Berwirausaha (Y). Hal tersebut dibuktikan dengan nilai $r$ hitung sebesar 0,289 yang berarti tidak terdapat tanda negatif pada $r$ hitung tersebut, sehingga hipotesis tersebut positif. Sedangkan harga $r$ hitung 0,289 yang lebih besar dari pada $\mathrm{r}$ tabel 0,244 dengan $\mathrm{N}=62$ dan taraf signifikansi 5\%, sehingga dapat disimpulkan bahwa hipotesis tersebut bernilai signifikan. Hal senada juga di sampaikan oleh (Antawati, 2017) dalam penelitiannya menyimpulkan bahwa bahwa peran orang tua sangat penting dalam pengembangan intensi berwirausaha pada anak. Namun, tidak banyak orang tua yang menyadari hal ini dan lebih mengandalkan sistem pendidikan formal untuk melakukan tugas tersebut. Pada dasarnya semua pihak bertanggung jawab atas pendidikan anak-anak, kerjasama di antara mereka sangat penting, karena pendidikan yang komprehensif akan membawa hasil yang lebih matang daripada usaha yang dilakukan secara sporadis dan parsial. 


\section{Pengaruh pendidikan kewirausahan dan peran orang tua terhadap intensi berwirausaha.}

Berdasarkan hasil analisis data dan uji hipotesis yang dilakukan oleh peneliti dari angket yang disebar kepada mahasiswa, diketahui pendidikan kewirausahan dan peran orang tua berpengaruh signifikan terhadap intensi berwirausaha. Hal ini dapat dibuktikan dengan hasil analisis uji $\mathrm{F} 0,000<0,05$ dan $\mathrm{F}_{\text {hitung }}>\mathrm{F}_{\text {tabel }} 41,853>3,10$ sehingga hipotesis nol $\left(\mathrm{H}_{0}\right)$ ditolak dan hipotesis alternative diterima $\left(\mathrm{H}_{\mathrm{a}}\right)$. Yang berarti terdapat pengruh yang signifikan antara variabel pendidikan kewirausahaan $\left(\mathrm{X}_{1}\right)$ dan variabel peran orang tua $\left.\mathrm{X}_{2}\right)$ terhadap variabel Intensi berwirausaha (Y) mahasiswa prodi pendidikan ekonomi semester VI STKIP PGRI Tulungagung. Artinya bahwa pendidikan kewirausahaan dan peran orang tua merupakan faktor penting yang mempengaruhi intensi berwirausaha seorang mahasiswa, untuk mencapai sebuah kesuksesan, kesejahteraan dan kehidupan yang lebih baik dimasa depan. pendidikan kewirausahaan yang diajarkan pada saat kuliah akan menjadi belak yang cukup uuntuk mahasiswa mampu mengolah dan mengimplementasikan ilmu yang diberikan yaitu dengan cara membuat sebuah usaha, serta peran orang tua yang selaku mendukung, mensupport dan membiayai segala kebutuhan baik itu berupa materi maupun dukungan psikis akan menjadi sebuah sinergi yang sangat baik yang mampu menumbuhkan intensi berwirausaha mahasiswa.

Sedangkan koefisien korelasi (r) antara pendidikan kewirausahaan dan peran orang tua terhadap intensi berwirausaha mahasiswa prodi pendidikan ekonomi STKIP PGRI Tulungagung adalah sebesar 0,702 dengan nilai koefisien determinan $\left(\mathrm{r}^{2}\right)$ dari persamaan regresi adalah sebesar 0,493 . Hal ini menunjukkan Variabel $\mathrm{X}_{1}$ (pendidikan kewirausahan) dan $\mathrm{X}_{2}$ (peran orang tua) mempengaruhi variabel Y(intensi berwirausaha mahasiswa prodi pendidikan ekonomi semester VI STKIP PGRI Tulungagung) sebesar 49,3\%, dengan sumbangan efektif variabel pendidikan kewirausahaan $\left(\mathrm{X}_{1}\right)$ sebesar $25,7842 \%$ dan variabel peran orang tua $\left(X_{2}\right)$ sebesar 23,4824\% sedangkan sisanya dipengaruhi oleh faktor-faktor diluar variabel dalam penelitian ini yaitu $50,7 \%$. 


\section{KESIMPULAN}

Berdasarkan hasil penelitian dan pembahasan hasil penelitian yang telah dilakukan dapat disimpulkan:

1. Ada pengaruh yang signifikan pendidikan kewirausahaan $\left(X_{1}\right)$ sebesar 4,832 terhadap intensi berwirausaha mahasiswa semester VI Prodi Pendidikan Ekonomi STKIPPGRI Tulungagung Tahun akademik 2017/2018. Hal ini berarti semakin baik pendidikan kewirausahaan maka akan meningkatkan intensi berwirausaha mahasiswa.

2. Ada pengaruh yang signifikan peran orang tua $\left(X_{2}\right)$ sebesar 4,513 terhadap intensi berwirausaha mahasiswa semester VI Prodi Pendidikan Ekonomi STKIPPGRI Tulungagung Tahun akademik 2017/2018.Hal ini berarti peran orang tua penting dalam menumbuhkan intensi berwirausaha pada anak/mahasiswa.

3. Ada pengaruh yang signifikan pendidikan kewirausahaan dan peran orang tua sebesar 41,853 terhadap intensi berwirausaha mahasiswa semester VI Prodi Pendidikan Ekonomi STKIPPGRI Tulungagung Tahun akademik 2017/2018. Artinya bahwa pendidikan kewirausahaan dan peran orang tua merupakan faktor penting yang mempengaruhi intensi berwirausaha seorang mahasiswa, untuk mencapai sebuah kesuksesan, kesejahteraan dan kehidupan yang lebih baik dimasa depan.

\section{DAFTAR PUSTAKA}

Alma, Buchari. 2011. Kewirausahaan.Bandung:Alfabeta

Antawati, D. I. (2017). Peran Orang Tua Dalam Menumbuhkan Intensi Berwirausaha Pada Anak, 1, 46-54.

BPS Survei Angkatan Kerja Nasional (Sakernas) Tahun 2013-2017 Tentang Pengangguran Terbuka Menurut Pendidikan Tertinggi Yang Ditamatkan Tahun 2017 Jakarta:Bps

Cahyono, A. E. 2014. Pengaruh Pendidikan Kewirausahaan Melalui Variabel Intervening Teori Perilaku Terencana Terhadap Intensi Berwirausaha Mahasiswa Fakultas Keguruan dan Ilmu Pendidikan Universitas Jember, 252-263

Daryanto. (2012). Pendidikan Kewirausahaan. Yogyakarta: Gava Media.

Etriyani, Y. E., \& Purwanto. (2014). Pengaruh Kreativitas,Peran Orang Tua Dan Efikasi Diri Terhadap Intensi Berwirausaha Siswa Kompetensi Keahlian Administrasi Perkantoran Smkn 1 Pengasih, 1-12. 
Fradani, A. C. (2014). Pengaruh Kecerdasan Adversitas, Pendidikan Kewirausahaan Dalam Keluarga, Dukungan Keluarga, Efikasi Diri Pada Intensi Berwirausaha Siswa Smkn 2 Nganjuk, 2(2), 157-170.

Kasmir,2006. Kewirausahaan, Jakarta:Pt Raja Grafindo Persada

K, R. P. D., Dedi Purwana, E., \& Wibowo, A. (2017). Hubungan Pola Asuh, Kurikulum Kewirausahaan Dan Intensi Berwirausaha Mahasiswa Fakultas Ekonomi Universitas Negeri Jakarta, 5(1), 1-31.

Kristianten, Stein \& Nurul Indarti,2003, Determinans Of Enterpreneurial Intention:The Case Of Norwegian Student. International Journal Of Bussiness Gajah Mada. Vol 5 No 1 Januari.

Mutohar, A. (2017). Pengaruh Kebutuhan Akan Prestasi, Efikasi Diri, Kesiapan Instrumen, Dan Pendidikan Kewirausahaan Terhadap Intensi Berwirausaha Mahasiswa (Studi Analisis Pada Mahasiswa Jurusan Manajemen Bisnis Syariah Angkatan 2013), 1-125.

Ningsih, Setya. (2013). Peran Orang Tua Terhadap Motivasi Belajar Anak Di Sekolah (Studi Di Smp Muhammadiyah 1 Berbah Sleman, Yogyakarta.) Skripsi. Skripsi, Hal 1.

Rusdiana.2012.Kewirausahaan.Bandung:Pustaka setia

Santi, N., Hamzah, A., \& Rahmawati, T. (2017). Pengaruh Efikasi Diri , Norma Subjektif , Sikap Berperilaku, dan Pendidikan, 1(1), 63-74.

Sari, A. K. (2013). Pengaruh Peran Orang Tua,Guru, dan self-efficay terhadap kesiapan berwirausaha.

Sugiyono, 2015. Metode Penelitian Pendidikan, Bandung:Alfabeta

Tatang S. (2012). Ilmu Pendidikan. Bandung: Cv Pustaka Setia

Trisnawati, E. (2011). Pengaruh Pendidikan Kewirausahaan Terhadap Intensi Berwirausaha Mahasiswa Institut Pertanian Bogor Melalui Pendekatan Theory Of Planned Behaviour.

Widayoko. (2016). Pengaruh Efikasi Diri, Norma Subyektif,Sikap Berperilaku, Dan Pendidikan Kewirausahaan Terhadap Intensi Berwirausaha Mahasiswa Fakultas Ekonomi Universitas Negeri Yogyakarta.

Yuniasanti, R., \& Esterlita, S. (2014). Pengaruh Pendidikan Kewirausahaan Terhadap Intensi Berwirausaha Mahasiswa Universitas Mercu Buana Yogyakarta, 1-16. 